\title{
Alpha B-crystallin is a new prognostic marker for laryngeal squamous cell carcinoma
}

Yuan Mao ${ }^{1 \dagger}$, Da-Wei Zhang ${ }^{2 \dagger}$, Hong Lin ${ }^{3}$, Lin Xiong ${ }^{4}$, Ying Liu', Qing-Dong Li', Jun Ma ${ }^{5}$, Qing Cao ${ }^{2}$, Ren-Jie Chen ${ }^{2 *}$, Jin Zhu $u^{6,7^{*}}$ and Zhen-Qing Feng ${ }^{6}$

\begin{abstract}
Background: Alpha B-crystallin (aB-crystallin) has been suggested to play an important role in the development of solid tumors. However, the association between aB-crystallin expression and clinicopathological characteristics of human laryngeal carcinoma is not well defined. This study aimed to examine the expression of aB-crystallin in human laryngeal squamous cell carcinoma (LSCC) and investigate the relationship between its expression and the prognosis of LSCC.

Methods: Real-time polymerase chain reaction (six LSCC samples, six tumor-adjacent normal samples) and immunohistochemistry by tissue microarrays (109 LSCC samples and 28 tumor-adjacent normal samples) were performed to characterize expression of the aB-crystallin gene in LSCC. Kaplan-Meier survival and Cox regression analyses were carried out to evaluate the prognosis of LSCC.

Results: Real-time polymerase chain reaction and immunohistochemistry analysis showed that the expression of aB-crystallin in LSCC was significantly higher than that in tumor-adjacent normal tissues. Moreover, the expression level of aB-crystallin protein in LSCC was significantly related to alcohol consumption ( $P=0.022)$, tumor differentiation ( $P=0.007)$, pTNM stage $(P=0.041)$ and 5 years' survival $(P=0.030)$. COX multi-factor analysis showed that aB-crystallin $(P=0.013)$, as well as pTNM stage $(P=0.027)$ and lymphatic metastasis $(P=0.015)$ were independent prognosis factors for LSCC.
\end{abstract}

Conclusions: The data suggest that aB-crystallin expression is correlated with malignant phenotypes of LSCC and it may serve as a novel prognostic factor for LSCC.

Keywords: Laryngeal carcinoma, Alpha B-crystallin gene, RT-PCR, QPCR, Immunohistochemistry, Prognosis

\section{Introduction}

Squamous cell carcinoma (SCC) of the head and neck is one of the most frequent malignancies in the world, with about a quarter of all cases occurring in the developing countries. SCC accounts for nearly $90 \%$ of all head and neck carcinomas [1]. Approximately, one-fourth of all head and neck cancers are laryngeal squamous cell carcinoma (LSCC). LSCC is a malignant tumor of laryngeal epithelial origin and the clinical symptoms usually depend on

\footnotetext{
* Correspondence: renjiechenent@yahoo.com.cn; zjsimmons@yahoo.com.cn ${ }^{\dagger}$ Equal contributors

${ }^{2}$ Department of Otolaryngology-Head and Neck Surgery, The Second Affiliated Hospital of Nanjing Medical University, No.121 Jiang jia yuan, Nanjing 210011, China

${ }^{6}$ The Key Laboratory of Cancer Biomarkers, Prevention \& Treatment Cancer Center and The Key Laboratory of Antibody Technique of Ministry of Health, Nanjing Medical University, No.140 Hanzhong Road, Nanjing 210029, China Full list of author information is available at the end of the article
}

its original site and size [2,3]. Although several cuttingedge treatment strategies have been developed for LSCC, no treatment could achieve a satisfactory therapeutic outcome and the mortality rate of LSCC is still high (5-year survival rate is 64\%) [4]. Therefore, it is urgent to develop novel and valuable markers to distinguish patients with poor prognosis or at high risk of early recurrence and guide chemotherapy and radiotherapy [5].

Alpha B-crystallin ( $\alpha \mathrm{B}$-crystallin) is a member of the small heat shock protein (sHSP) family and acts as a molecular chaperone, by preventing the aggregation of denatured proteins after the exposure to stresses such as heat shock, radiation, oxidative stress and anticancer drugs [6]. Moreover, ectopic expression of $\alpha \mathrm{B}$-crystallin in diverse cell types confers protection against a variety of apoptotic stimuli, including TNF- $\alpha$, TNF-related 
apoptosis-inducing ligand (TRAIL), etoposide and growth factor deprivation $[7,8]$. It is believed that $\alpha B$-crystallin can interact with different apoptotic proteins to regulate apoptosis [9]. Recent studies suggest that $\alpha \mathrm{B}$-crystallin is a prognostic marker for various types of solid tumors [10-12]. $\alpha$ B-crystallin may play a role in tumorigenesis by modulating vascular endothelial growth factor (VEGF) $[13,14]$. However, the expression and function of $\alpha \mathrm{B}$ crystallin in LSCC have not been determined.

In this study, we examined the expression levels of $\alpha \mathrm{B}$-crystallin in LSCC tissues and tumor-adjacent normal tissues. The results showed that compared to tumoradjacent normal tissues, $\alpha \mathrm{B}$-crystallin expression was higher in LSCC tissues. In addition, $\alpha \mathrm{B}$-crystallin expression in LSCC was associated with alcohol consumption, tumor differentiation, pTNM stage and 5-year survival.

\section{Materials and methods}

\section{Patient specimens}

A total of one hundred and nine cases of LSCC were collected from the Department of Pathology, the Affiliated Hospital of Nantong University between 2000 and 2009. Diagnosis of LSCC was determined according to the latest WHO criteria [15] and TNM stage classification (UICC 2002). Among the cases, there were 107 men and 2 women. The mean age of patients at the time of surgery was 60.8 years (ranging from 29 to 87 years). Related clinical data were collected, including gender, age, tobacco and alcohol consumption, tumor differentiation, pTNM stage, lymph node metastasis, and 5-year follow-up survival. Follow-up in all patients started from post-operation of May 2010. None of the 109 patients had performed radiotherapy, chemotherapy or immunotherapy before the surgery. Study protocol was approved by the Ethics Committee of Jiangsu Province Official Hospital.

\section{Reverse transcription-polymerase chain reaction (RT-PCR) and quantitative real-time polymerase chain reaction analysis (qPCR)}

Six samples of fresh LSCC tissues and their adjacent tissues were collected from the Department of Otolaryngology-Head and Neck Surgery, the Second Affiliated Hospital of Nanjing Medical University and the Department of Otolaryngology-Head and Neck Surgery, Yiji Shan Hospital of Wannan Medical College. Total RNA was extracted from LSCC tissues and tumoradjacent tissues by using Trizol reagent (Invitrogen, Carlsbad, CA) according to the manufacturer's protocol. RNA ( $2 \mu \mathrm{g}$ ) was reverse transcribed using High-Capacity cDNA Archive Kit (Promega) in accordance with the manufacturer's protocols. Primers were as follows: $\alpha B-$ crystallin forward 5'-CTTTGACCAGTTCTTCGGAG3', reverse 5'-CCTCAATCACATCTCCCAAC-3'; $\beta$-actin forward 5'- CTCCATCCTGGCCTCGCTGT-3', reverse
5'- GCTGCTACCTTCACCGTTCC-3'. The transcription levels of $\beta$-actin served as a loading control. Analysis of qPCR was performed using SYBR green dye in an ABI PRISM 7000HT Sequence Detection System (Applied Biosystems, Foster City, CA, USA) following the manufacturer's instructions. Cycle conditions were as follows: after an initial incubation at $50^{\circ} \mathrm{C}$ for 2 -min and at $95^{\circ} \mathrm{C}$ for $10 \mathrm{~min}$, the samples were cycled 40 times at $95^{\circ} \mathrm{C}$ for 15 seconds and $56^{\circ} \mathrm{C}$ for $1 \mathrm{~min}$.

\section{Tissue microarrays (TMA) construction and immunohistochemistry}

Formalin-fixed, paraffin-embedded tissues from 109 LSCC and 28 tumor-adjacent normal tissues were prepared and utilized in this present study. TMA was produced by Xinchao Biotech (Shanghai, China). Core tissue biopsies ( $2 \mathrm{~mm}$ in diameter) were taken from individual paraffinembedded LSCC and arranged in the new recipient paraffin blocks. Tissue microarray was cut into $4-\mu \mathrm{m}$ sections and placed on super frost charged glass microscope slides.

Paraffin tissue sections $(4 \mu \mathrm{m})$ were deparaffinized in $100 \%$ xylene and re-hydrated in descending ethanol series and water according to standard protocols. Heat-induced antigen retrieval was performed in $10 \mathrm{mM}$ citrate buffer for $2 \mathrm{~min}$ at $100^{\circ} \mathrm{C}$. Endogenous peroxidase activity was blocked by hydrogen peroxidase (3\%) in Tris-buffered saline (TBS) for $30 \mathrm{~min}$. Then the sections were boiled for $10 \mathrm{~min}$ in citrate buffer for antigen retrieval. Nonspecific binding was blocked by incubation with $5 \%$ goat serum in TBS for $30 \mathrm{~min}$. Tissue sections were incubated with mouse anti- $\alpha \mathrm{B}$-crystallin antibody (Stressgen, Victoria, Canada; 1:300) in TBS containing $1 \%$ bovine serum albumin for $1 \mathrm{~h}$. After washing, sections were incubated with EnVision goat anti-mouse/ horseradish peroxidase antibody (EB-2305, ZhongShan, Godbridge, China; 1:2000) for $1 \mathrm{~h}$. The replacement of the primary antibody with PBS served as negative controls. Finally, the sections were developed with 3,3-diaminobenzidine (DAB) chromogen solution and counterstained with hematoxylin. Four fields in each slide were randomly selected and counted, and the percentage of positive staining was determined by two clinical pathologists independently using immunohistochemistry score (IHS) [16]. When a conclusion differed, the final decision was made by consensus. The results were analyzed according to the method described previously [17]. Briefly, IHS was determined by the evaluation of both staining density and intensity. The percentage of positive tumor cells was scored as follows: 1 (0-10\% positive cells), 2 (11-50\% positive cells), 3 (51-80\% positive cells), 4 (81-100\% positive cells); and the intensity of staining was scored as follows: 0 (negative), 1 (weakly positive), 2 (moderately positive), and 3 (strongly positive). Multiplication of the intensity and the percentage scores gave 


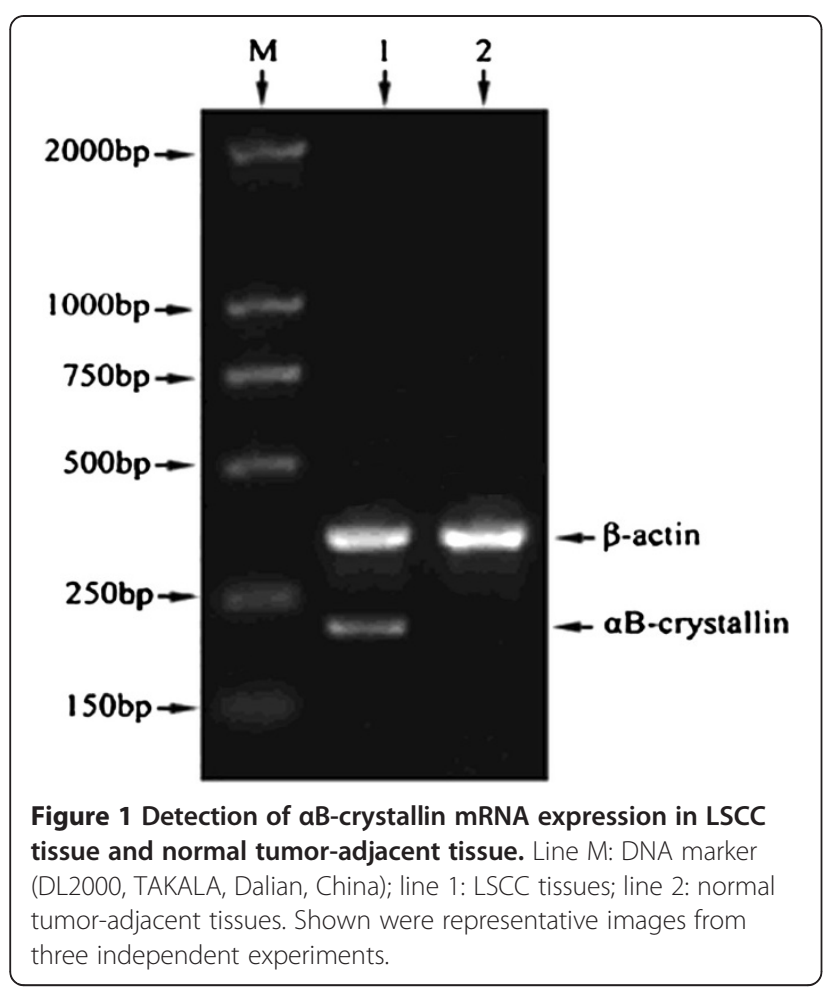

rise to the ultimate IHS: a sum score below 3 indicated low expression of $\alpha \mathrm{B}$-crystallin, and a sum score above 4 indicated high expression of $\alpha \mathrm{B}$-crystallin.

\section{Statistical analysis}

The relationship between $\alpha \mathrm{B}$-crystallin expression and clinicopathological factors was analyzed by chi-square test. Survival rate was estimated by Kaplan-Meier method. Univariate and multivariate analysis was carried out using Cox's proportional hazards regression models. For all tests, the significance level for statistical analysis was set at $\mathrm{P}<0.05$. Statistical analyses were performed using STATA Version 12.0 (Stata Corporation, College Station, TX).

\section{Result}

\section{High expression of aB-crystallin mRNA in LSCC}

RT-PCR amplicons were detected by $1.5 \%$ agarose gel electrophoresis, confirming that $\alpha \mathrm{B}$-crystallin was expressed in LSCC tissues (Figure 1). Moreover, mRNA levels of $\alpha \mathrm{B}$-crystallin in LSCC tissues and tumoradjacent tissues were determined by qPCR. Normalized to $\beta$-actin, $\alpha \mathrm{B}$-crystallin mRNA level in LSCC tissues $(n=6)$ and tumor-adjacent normal tissues $(n=6)$ was $6.808 \pm 1.781$ and $2.475 \pm 0.757$, respectively $(t=5.484$, $\mathrm{P}=0.001)$. mRNA level of $\alpha \mathrm{B}$-crystallin was significantly higher in LSCC than in tumor-adjacent normal tissues (Figure 2).

\section{aB-crystallin protein level is correlated with the} clinicopathologic factors of LSCC

By immunohistochemistry analysis, we observed more positive staining cells and stronger staining in LSCC tissues than in tumor-adjacent normal tissues (Figure 3). The positive staining was localized mainly in the cytoplasm of the tumor cells and strong staining was not observed in the surrounding tumor-adjacent areas.

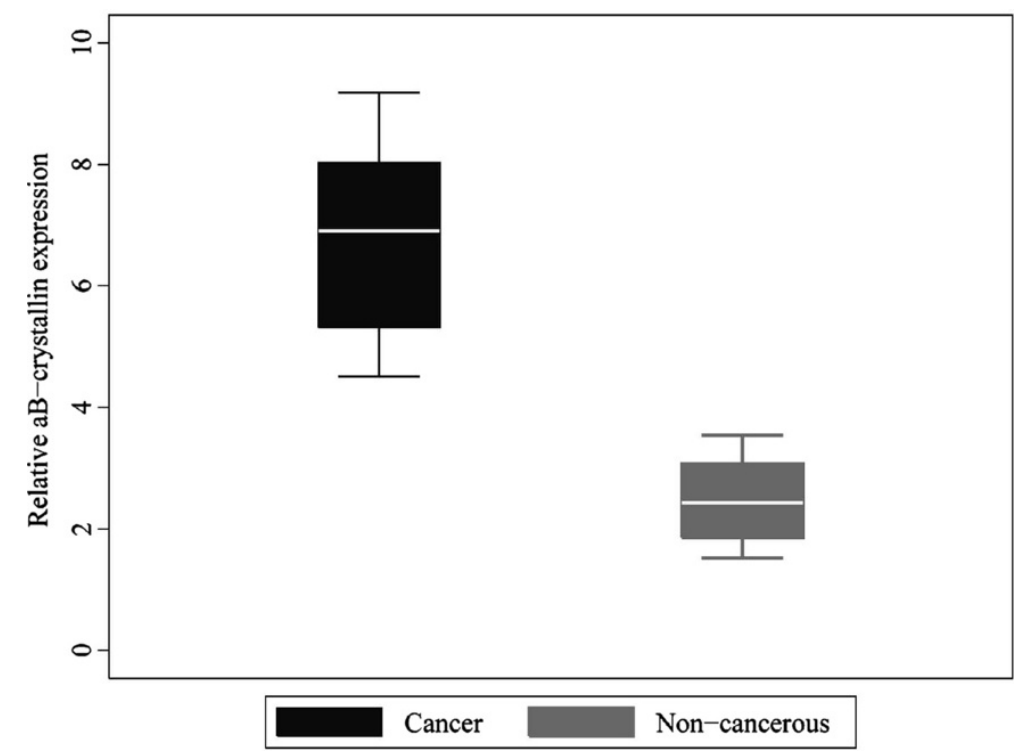

Figure $\mathbf{2}$ The mRNA levels of aB-crystallin determined by qPCR. The relative mRNA level of aB-crystallin was higher in LSCC than in normal tumor-adjacent tissue $(p<0.05)$. 


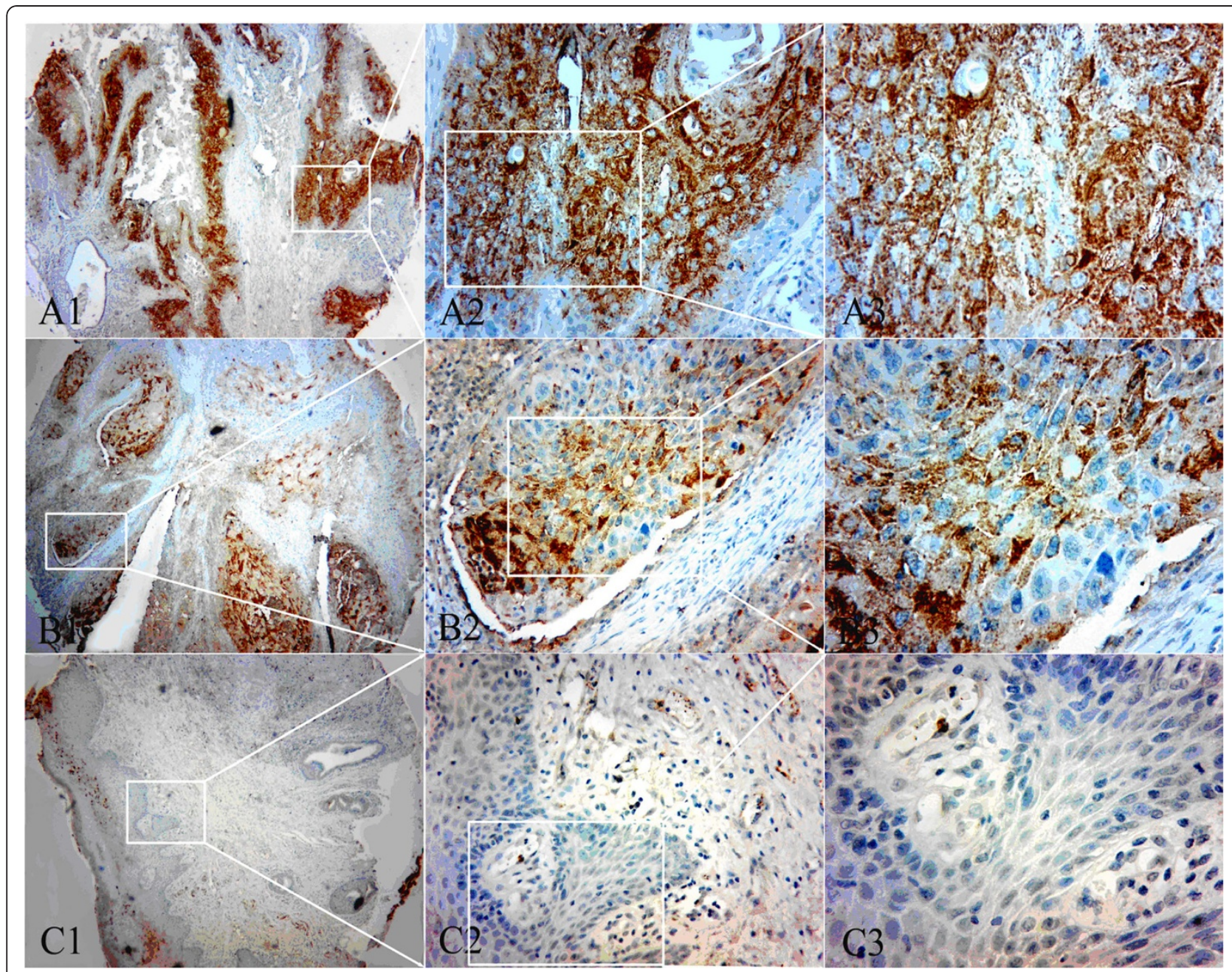

Figure 3 Expression pattern of aB-crystallin in tumor tissue and tumor-adjacent tissue of LSCC. TMA sections were analyzed by immunohistochemical staining. Brown staining indicated positive expression of aB-crystallin. A1-3: The expression pattern of aB-crystallin in moderately differentiated LSCC tissue. B1-3: The expression pattern of aB-crystallin in well-differentiated LSCC tissue. C1-2: The expression pattern of aB-crystallin in tumor-adjacent tissue with weakly positive staining of aB-crystallin. C3: Squamous epithelium of adjacent nontumorous tissue with negative staining of aB-crystallin. Original magnification: $\times 40$ in $A 1, B 1$ and $C 1 ; \times 100$ in $A 2, B 2$ and $C 2 ; \times 400$ in $A 3, B 3$ and $C 3$.

Positive staining of $\alpha B$-crystallin was detected in $64(58.72 \%)$ of 109 LSCC samples, while only 5 cases of 28 tumor-adjacent normal tissues (17.86\%) displayed high expression of $\alpha \mathrm{B}$-crystallin. There was significant difference in high expression rate of $\alpha \mathrm{B}$-crystallin between LSCC tissues and normal non-cancerous tissues $(\mathrm{P}=0.001)$.

Correlations between various clinicopathological characteristics and $\alpha B$-crystallin expression in LSCC tissues were evaluated by $\chi^{2}$ test (Table 1 ). The result showed that high expression of $\alpha \mathrm{B}$-crystallin in LSCC was significantly related to alcohol consumption $(\mathrm{P}=0.022)$, tumor differentiation $(\mathrm{P}=0.007)$, pTNM stage $(\mathrm{P}=0.041)$ and 5-year survival $(\mathrm{P}=0.030)$. However, no statistically significant correlation was found between $\alpha \mathrm{B}$-crystallin expression and gender, age, tobacco use, or lymph node metastasis.

\section{Survival analysis}

Univariate analysis showed that the life span of LSCC patients was correlated with $\alpha \mathrm{B}$-crystallin expression $(\mathrm{P}=0.010)$, pTNM stage $(\mathrm{P}<0.001)$, lymph node metastasis $(\mathrm{P}<0.001)$ and tumor differentiation $(\mathrm{P}=0.022)$. Multivariate analysis with the Cox regression model indicated that $\alpha \mathrm{B}$-crystallin protein level may serve as an independent prognostic factor for overall survival $(\mathrm{P}=0.013)$ (Table 2). Furthermore, pTNM stage $(\mathrm{P}=0.027)$ and lymph node metastasis $(\mathrm{P}=0.015)$ were identified as independent predictive factors for poor outcome of LSCC. Kaplan-Meier survival curves showed 
Table 1 Correlation of aB-crystallin expression with clinicopathological characteristics of LSCC

\begin{tabular}{|c|c|c|c|c|c|}
\hline \multirow[t]{2}{*}{ Groups } & \multirow[t]{2}{*}{ No. } & \multicolumn{2}{|c|}{ aB-crystallin } & \multirow[t]{2}{*}{$x^{2}$} & \multirow[t]{2}{*}{$\mathrm{P}$ (value) } \\
\hline & & + & $\%$ & & \\
\hline \multicolumn{6}{|l|}{ Gender } \\
\hline Male & 107 & 63 & 58.88 & 0.0638 & 0.801 \\
\hline Female & 2 & 1 & 50.00 & & \\
\hline \multicolumn{6}{|l|}{ Age(years) } \\
\hline$\leq 60 y$ & 45 & 23 & 51.11 & 1.8283 & 0.176 \\
\hline$>60 y$ & 64 & 41 & 64.06 & & \\
\hline \multicolumn{6}{|l|}{ Tobacco use } \\
\hline Yes & 77 & 42 & 54.55 & 1.8816 & 0.170 \\
\hline No & 32 & 22 & 68.75 & & \\
\hline \multicolumn{6}{|c|}{ Alcohol consumption } \\
\hline Yes & 53 & 37 & 69.81 & 5.2395 & $0.022^{*}$ \\
\hline No & 56 & 27 & 48.21 & & \\
\hline \multicolumn{6}{|c|}{ Tumor differentiation } \\
\hline Well & 51 & 22 & 43.14 & 9.9434 & $0.007^{*}$ \\
\hline Moderate & 53 & 39 & 71.70 & & \\
\hline Poor & 5 & 3 & 80.00 & & \\
\hline \multicolumn{6}{|l|}{ pTNM stage } \\
\hline Stage I, II & 65 & 33 & 50.77 & 4.1945 & $0.041^{*}$ \\
\hline Stage III, IV & 44 & 31 & 70.45 & & \\
\hline \multicolumn{6}{|c|}{ Lymph node metastasis } \\
\hline Yes & 19 & 14 & 73.68 & 2.1270 & 0.145 \\
\hline No & 90 & 50 & 55.56 & & \\
\hline \multicolumn{6}{|c|}{ Five years' survival } \\
\hline Yes & 72 & 37 & 51.39 & 4.6972 & $0.030^{*}$ \\
\hline No & 37 & 27 & 72.98 & & \\
\hline
\end{tabular}

that patients with high $\alpha \mathrm{B}$-crystallin expression had a shorter survival time than patients with low $\alpha B$-crystallin expression (Figure 4). Kaplan-Meier survival curves demonstrated that patients with high $\alpha \mathrm{B}$-crystallin expression, advanced pTNM stage of LSCC and lymph node metastasis had a significantly shorter survival time.

\section{Discussion}

Several state-of-the-art treatment strategies have been developed for LSCC, including molecular targeted therapy [18], gene therapy [19] and immunotherapy [20]. However, no treatment could achieve satisfactory therapeutic outcome and the survival rate of LSCC has not been improved significantly [21]. Recent studies suggest several molecular markers of LSCC [22-24]. Further identification of prognostic markers for LSCC will be important for the prevention and therapy of LSCC.

$\alpha B$-crystallin has been shown to be overexpressed in numerous kinds of tumors, including gliomas, prostate cancer, oral squamous cell carcinomas, renal cell carcinomas, and head and neck cancer [25]. Recently, an oncogenic role of $\alpha \mathrm{B}$-crystallin has been proposed for breast cancer [26]. The neoplastic changes and invasive phenotypes of breast cells and the anti-apopototic activities of $\alpha \mathrm{B}$-crystallin were inhibited by the phosphorylation of $\alpha \mathrm{B}$-crystallin $[27,28]$. Furthermore, $\alpha \mathrm{B}$-crystallin could promote tumor angiogenesis by modulating VEGF $[13,14]$. These studies demonstrate that $\alpha \mathrm{B}$-crystallin plays crucial role in tumor progression.

In the present study, the mRNA and protein levels of $\alpha B$-crystallin in LSCC and tumor-adjacent normal tissues were detected by qPCR and immunohistochemistry. Both analyses showed that $\alpha B$-crystallin was highly

Table 2 Univariate and multivariable analysis of prognostic factors in LSCC for 5-year survival

\begin{tabular}{|c|c|c|c|c|c|c|}
\hline & \multicolumn{3}{|c|}{ Univariate analysis } & \multicolumn{3}{|c|}{ Multivariable analysis } \\
\hline & $\overline{\mathrm{HR}}$ & $p>|z|$ & $95 \% \mathrm{Cl}$ & $\overline{\mathrm{HR}}$ & $p>|z|$ & $95 \% \mathrm{Cl}$ \\
\hline \multicolumn{7}{|l|}{ aB-crystallin expression } \\
\hline High versus Low & 2.508 & $0.010^{*}$ & $1.245-5.051$ & 2.498 & $0.013^{*}$ & $1.218-5.124$ \\
\hline \multicolumn{7}{|l|}{ Age (years) } \\
\hline$\leq 60 y$ versus $>60 y$ & 0.613 & 0.148 & $0.316-1.189$ & & & \\
\hline \multicolumn{7}{|l|}{ Tobacco use } \\
\hline Yes versus No & 0.643 & 0.203 & $0.325-1.270$ & & & \\
\hline \multicolumn{7}{|l|}{ Alcohol consumption } \\
\hline Yes versus No & 0.903 & 0.747 & $0.485-1.680$ & & & \\
\hline \multicolumn{7}{|l|}{ pTNM stage } \\
\hline Stage I, II versus Stage III, IV & 0.291 & $0.001^{*}$ & $0.151-0.561$ & 0.426 & $0.027^{*}$ & $0.200-0.908$ \\
\hline \multicolumn{7}{|l|}{ Lymph node metastasis } \\
\hline Yes versus No & 4.412 & $0.001^{*}$ & $2.225-8.748$ & 2.707 & $0.015^{*}$ & $1.215-6.034$ \\
\hline \multicolumn{7}{|l|}{ Tumor differentiation } \\
\hline Well versus Moderate-Poor & 0.478 & $0.022^{*}$ & $0.255-0.897$ & 0.594 & 0.107 & $0.315-1.120$ \\
\hline
\end{tabular}



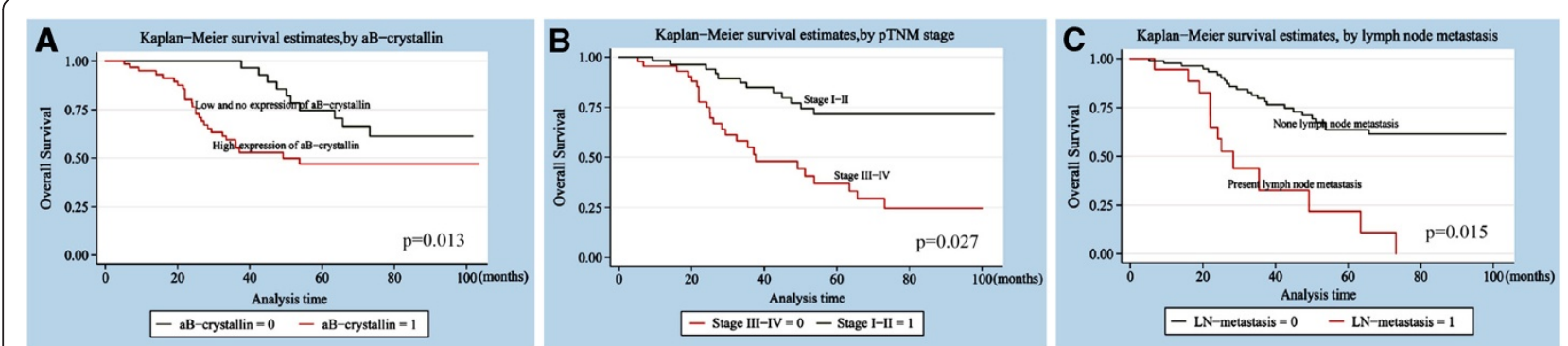

Figure 4 Survival curves of LSCC patients based on various independent factors. A: Overall survival rate in patients with positive expression of aB-crystallin (red line, aB-crystallin =1) was significantly lower than that in patients with negative aB-crystallin expression (green line, aB-crystallin =0). B: Overall survival rate in patients with stage III-IV of LSCC (red line, stage III-IV $=0$ ) was significantly lower than that in patients with stage I-II of LSCC (green line, stage $I-\|=1$ ). C: Overall survival rate in patients with lymph node metastasis (red line, LN metastasis = 1) was significantly lower than that in patients without lymph node metastasis (green line, LN metastasis $=0$ ).

expressed in LSCC compared to tumor-adjacent normal tissues. These results agree with previous report which showed that $\alpha \mathrm{B}$-crystallin was overexpressed in hepatocellular carcinoma cells compared with non-tumour cells [11]. Moreover, we found that the high expression of $\alpha \mathrm{B}$-crystallin in LSCC was related to alcohol consumption, tumor differentiation, pTNM stage and 5-year survival.

Univariate analysis showed that not only $\alpha \mathrm{B}$-crystallin expression, but also the pTNM stage, lymph node metastasis and tumor differentiation were correlated with life span of LSCC patients. Multivariate analysis revealed that strong expression of $\alpha \mathrm{B}$-crystallin could be considered as an independent factor for poor prognosis of LSCC patients, as well as PTNM stage and lymph node metastasis.

Interestingly, several studies suggest that $\alpha \mathrm{B}$-crystallin acts as a tumor suppressor gene in certain types of cancer [29-31]. In addition, $\alpha B$-crystallin staining was reported to be reduced in head and neck squamous cell carcinoma and $\alpha \mathrm{B}$-crystallin was not proposed as a prognostic marker [32,33]. Our present data are inconsistent with these studies. These conflicting results may be due to the differences in the pathological samples, the antibodies used, the experimental methods or evaluation system.

In conclusion, to the best of our knowledge, this is the first study to report that high $\alpha \mathrm{B}$-crystallin expression is correlated with aggressive malignant phenotype of LSCC. Our data indicate that $\alpha \mathrm{B}$-crystallin may serve as a novel prognostic marker for LSCC. Further studies are needed to confirm the prognostic and therapeutic value of $\alpha \mathrm{B}$-crystallin for LSCC.

\section{Conclusions}

Taken together, the results of this study suggest that $\alpha B$-crystallin expression is correlated with malignant phenotypes of LSCC and it may serve as a novel prognostic factor for LSCC.

\section{Competing interests}

The authors declared that they have no competing interest.

\section{Authors' contributions}

YM and DWZ design the study; HL, YL and QDL carried out the RT-PCR and QPCR analysis; LX, JM and QC peformed the immunohistochemistry; YM drafted the manuscript. All authors read and approved the final manuscript.

\section{Acknowledgments}

This work is supported by the grants from General Program of Jiangsu Province Official Hospital (No. L201109) and Youth Funds of Second Affiliated Hospital of Nanjing Medical University (No. QN201004)

\section{Author details}

'Department of Otolaryngology-Head and Neck Surgery, Jiangsu Province Official Hospital, No.65 Jiangsu Road, Nanjing 210029, China. ${ }^{2}$ Department of Otolaryngology-Head and Neck Surgery, The Second Affiliated Hospital of Nanjing Medical University, No.121 Jiang jia yuan, Nanjing 210011, China. ${ }^{3}$ Jiangsu Provincial Blood Center, No.179 Longpan Road, Nanjing 210042, China. ${ }^{4}$ Department of Pathology, The Second Affiliated Hospital of Nanjing Medical University, No.121 Jiang jia yuan, Nanjing 210011, China.

${ }^{5}$ Department of Otolaryngology-Head and Neck Surgery, Yiji Shan Hospital of Wannan Medical College, No.92 Zheshan Xi Road, Wuhu 241000, China. ${ }^{6}$ The Key Laboratory of Cancer Biomarkers, Prevention \& Treatment Cancer Center and The Key Laboratory of Antibody Technique of Ministry of Health, Nanjing Medical University, No.140 Hanzhong Road, Nanjing 210029, China. ${ }^{7}$ Huadong Medical Institute of Biotechnology, No.293 Zhongshan Dong Road, Nanjing 210002, China.

Received: 18 October 2012 Accepted: 6 December 2012 Published: 12 December 2012

\section{References}

1. Wu H, Xu H, Zhang S, Wang X, Zhu H, Zhang H, Zhu J, Huang J: Potential therapeutic target and independent prognostic marker of TROP2 in laryngeal squamous cell carcinoma. Head Neck 2012, doi:doi:10.1002/hed.23138.

2. Jemal A, Siegel R, Ward E, Hao Y, Xu J, Thun MJ: Cancer statistics, 2009. CA Cancer J Clin 2009, 59(4):225-249.

3. Hoffman HT, Porter K, Karnell LH, Cooper JS, Weber RS, Langer CJ, Ang KK, Gay G, Stewart A, Robinson RA: Laryngeal cancer in the United States: changes in demographics, patterns of care, and survival. Laryngoscope 2006, 116(9 Pt 2 Suppl 111):1-13.

4. Boyle P, Ferlay J: Cancer incidence and mortality in Europe. Ann Oncol 2005, 16(3):481-488.

5. Chin D, Boyle GM, Williams RM, Ferguson K, Pandeya N, Pedley J, Campbell CM, Theile DR, Parsons PG, Coman WB: Alpha B-crystallin, a new independent marker for poor prognosis in head and neck cancer. Laryngoscope 2005, 115(7):1239-1242.

6. Moyano JV, Evans JR, Chen F, Lu M, Werner ME, Yehiely F, Diaz LK, Turbin D, Karaca G, Wiley E, Nielsen TO, Perou CM, Cryns VL: AlphaB-crystallin is a 
novel oncoprotein that predicts poor clinical outcome in breast cancer. J Clin Invest 2006, 116(1):261-270.

7. Kamradt MC, Lu M, Werner ME, Kwan T, Chen F, Strohecker A, Oshita S, Wilkinson JC, Yu C, Oliver PG, Duckett CS, Buchsbaum DJ, LoBuglio AF, Jordan VC, Cryns VL: The small heat shock protein alpha B-crystallin is a novel inhibitor of TRAlL-induced apoptosis that suppresses the activation of caspase-3. J Biol Chem 2005, 280(12):11059-11066.

8. Adhikari AS, Singh BN, Rao KS, Rao CM: aB-crystallin, a small heat shock protein, modulates NF-KB activity in a phosphorylation-dependent manner and protects muscle myoblasts from TNF-a induced cytotoxicity. Biochim Biophys Acta 2011, 1813(8):1532-1542.

9. Mao YW, Liu JP, Xiang H, Li DW: Human alphaA- and alphaBcrystallins bind to $B a x$ and $B C l-X(S)$ to sequester their translocation during staurosporine-induced apoptosis. Cell Death Differ 2004, 11(5):512-526.

10. Chan SK, Lui PC, Tan PH, Yamaguchi R, Moriya T, Yu AM, Shao MM, Hliang T, Wong SI, Tse GM: Increased alpha-B-crystallin expression in mammary metaplastic carcinomas. Histopathology 2011, 59(2):247-255.

11. Tang Q, Liu YF, Zhu XJ, Li YH, Zhu J, Zhang JP, Feng ZQ, Guan XH: Expression and prognostic significance of the aB-crystallin gene in human hepatocellular carcinoma. Hum Pathol 2009, 40(3):300-305.

12. Stegh $\mathrm{AH}$, Kesari $\mathrm{S}$, Mahoney JE, Jeng $\mathrm{HT}$, Forloney $\mathrm{KL}$, Protopopov $\mathrm{A}$, Louis DN, Chin L, DePinho RA: Bcl2L12-mediated inhibition of effector caspase-3 and caspase-7 via distinct mechanisms in glioblastoma. Proc Natl Acad Sci USA 2008, 105(31):10703-10708.

13. Dimberg A, Rylova S, Dieterich LC, Olsson AK, Schiller P, Wikner C, Bohman S, Botling J, Lukinius A, Wawrousek EF, Claesson-Welsh L: alphaB-crystallin promotes tumor angiogenesis by increasing vascular survival during tube morphogenesis. Blood 2008, 111(4):2015-2023.

14. Kase S, He S, Sonoda S, Kitamura M, Spee C, Wawrousek E, Ryan SJ, Kannan R, Hinton DR: alphaB-crystallin regulation of angiogenesis by modulation of VEGF. Blood 2010, 115(16):3398-3406.

15. Thompson L: World Health Organization classification of tumours: pathology and genetics of head and neck tumours. Ear Nose Throat $J$ 2006, 85(2):74.

16. Friedrich M, Villena-Heinsen C, Reitnauer K, Schmidt W, Tilgen W, Reichrath J: Malignancies of the uterine corpus and immunoreactivity score of the DNA "mismatch-repair"enzyme human Mut-S-homologon-2. $J$ Histochem Cytochem 1999, 47(1):113-118.

17. Mao Y, Zhang DW, Wen J, Cao Q, Chen RJ, Zhu J, Feng ZQ: A novel LMP1 antibody synergizes with Mitomycin $C$ to inhibit Nasopharyngeal Carcinoma growth in vivo through inducing apoptosis and downregulating vascular endothelial growth factor. Int J Mol Sci 2012, 13(2):2208-2218

18. Luo XM, Zhou SH, Fan J: Glucose transporter-1 as a new therapeutic target in laryngeal carcinoma. J Int Med Res 2010, 38(6):1885-1892.

19. Chen J, Yang B, Zhang S, Ling Y, Ye J, Jia Z, Cao J: Antitumor potential of SLPI promoter controlled recombinant caspase-3 expression in laryngeal carcinoma. Cancer Gene Ther 2012, 19(5):328-335.

20. Liang W, Wang XF: In vitro induction of specific anti-tumoral immunity against laryngeal carcinoma by using human interleukin-12 gene-transfected dendritic cells. Chin Med J (Engl) 2011, 124(9):1357-1361.

21. de Souza DL B, Jerez Roig J, Bernal MM: Laryngeal cancer survival in Zaragoza (Spain): a population-based study. Clin Transl Oncol 2012, 14(3):221-224.

22. Liu Y, Dong XL, Tian C, Liu HG: Human telomerase RNA component (hTERC) gene amplification detected by FISH in precancerous lesions and carcinoma of the larynx. Diagn Pathol 2012, 7:34.

23. Shi Y, Gong HL, Zhou L, Tian J, Wang Y: CD24: a novel cancer biomarker in laryngeal squamous cell carcinoma. ORL J Otorhinolaryngol Relat Spec 2012, 74(2):78-85

24. Liu J, Lei DP, Jin T, Zhao XN, Li G, Pan XL: Altered expression of miR-21 and PTEN in human laryngeal and hypopharyngeal squamous cell carcinomas. Asian Pac J Cancer Prev 2011, 12(10):2653-2657.

25. Arrigo AP, Simon S, Gibert B, Kretz-Remy C, Nivon M, Czekalla A, Guillet D, Moulin M, Diaz-Latoud C, Vicart P: Hsp27 (HspB1) and alphaB-crystallin (HspB5) as therapeutic targets. FEBS Lett 2007, 581(19):3665-3674.

26. Gruvberger-Saal SK, Parsons R: Is the small heat shock protein alphaB-crystallin an oncogene? J Clin Invest 2006, 116(1):30-32

27. Chelouche-Lev D, Kluger HM, Berger AJ, Rimm DL, Price JE: alphaB-crystallin as a marker of lymphnode involvement in breast carcinoma. Cancer 2004, 100(12):2543-2548.
28. Jeong WJ, Rho JH, Yoon YG, Yoo SH, Jeong NY, Ryu WY, Ahn HB, Park WC, Rho SH, Yoon HS, Choi YH, Yoo YH: Cytoplasmic and nuclear antiapoptotic roles of aB-Crystallin in retinal pigment epithelial cells. PLoS One 2012, 7(9):e45754

29. Huang Z, Cheng Y, Chiu PM, Cheung FM, Nicholls JM, Kwong DL, Lee AW, Zabarovsky ER, Stanbridge EJ, Lung HL, Lung ML: Tumor suppressor Alpha B-crystallin (CRYAB) associates with the cadherin/catenin adherens junction and impairs NPC progression-associated properties. Oncogene 2012, 31(32):3709-3720.

30. Barbash O, Zamfirova P, Lin DI, Chen X, Yang K, Nakagawa H, Lu F, Rustgi AK, Diehl JA: Mutations in Fbx4 inhibit dimerization of the SCF (Fbx4) ligase and contribute to cyclin D1 overexpression in human cancer. Cancer Cell 2008, 14(1):68-78.

31. Stronach EA, Sellar GC, Blenkiron C, Rabiasz GJ, Taylor KJ, Miller EP, Massie CE, Al-Nafussi A, Smyth JF, Porteous DJ, Gabra H: Identification of clinically relevant genes on chromosome 11 in a functional model of ovarian cancer tumor suppression. Cancer Res 2003, 63(24):8648-8655.

32. Solares CA, Boyle GM, Brown I, Parsons PG, Panizza B: Reduced alphaB-crystallin staining in perineural invasion of head and neck cutaneous squamous cell carcinoma. Otolaryngol Head Neck Surg 2010, 142(3 Suppl 1):S15-S19.

33. Boslooper K, King-Yin Lam A, Gao J, Weinstein S, Johnson N: The clinicopathological roles of alpha-B-crystallin and p53 expression in patients with head and neck squamous cell carcinoma. Pathology 2008, 40(5):500-504

doi:10.1186/1756-9966-31-101

Cite this article as: Mao et al:: Alpha B-crystallin is a new prognostic marker for laryngeal squamous cell carcinoma. Journal of Experimental \& Clinical Cancer Research 2012 31:101.

\section{Submit your next manuscript to BioMed Central and take full advantage of:}

- Convenient online submission

- Thorough peer review

- No space constraints or color figure charges

- Immediate publication on acceptance

- Inclusion in PubMed, CAS, Scopus and Google Scholar

- Research which is freely available for redistribution 